\title{
Effect of plasma and/or yeast extract on performance and intestinal morphology of piglets from 7 to 63 days of age
}

\section{Leandro César Milagres Rigueira' ${ }^{1}$, Maria Cristina Thomaz², Dalton César Milagres Rigueira ${ }^{3}$, Leonardo Augusto Fonseca Pascoal ${ }^{4}$, Alessandro Borges Amorim ${ }^{5}$, Fábio Enrique Lemos Budiño ${ }^{6}$}

\author{
${ }_{1}$ Agroceres Nutrição Animal Ltda., Rio Claro/SP, Brazil, CEP 13502-741. \\ 2 Departamento de Zootecnia, Universidade Estadual Paulista, Jaboticabal/SP, Brazil, CEP 14884-900. \\ ${ }^{3}$ Departamento de Zootecnia, Centro Universitário de Patos de Minas, Patos de Minas/MG, Brazil, CEP 38702-054. \\ ${ }^{4}$ Departamento de Agropecuária, Universidade Federal da Paraíba, Bananeiras/PB, Brazil, CEP 58220-000. \\ ${ }^{5}$ Departamento de Produção Animal, Universidade Estadual Paulista, Botucatu/SP, Brazil, CEP 18618-000. \\ ${ }^{6}$ Centro de Pesquisa e Desenvolvimento em Zootecnia Diversificada, Instituto de Zootecnia, Nova Odessa/SP, Brazil, CEP $13460-000$.
}

\begin{abstract}
The objective of this study was to evaluate the effect of diets supplemented with plasma and/or yeast extract on performance (daily weight gain [DWG], daily feed intake [DFI] and feed conversion [FC]) and intestinal morphology of piglets from 7 to 63 days of age. A total of 288 piglets aged 7 days and weighing $2.57 \pm 0.05 \mathrm{~kg}$ were studied. A randomized block design consisting of four experimental diets, six repetitions and 12 piglets per experimental unit was adopted. The prestarter I ( 7 to 21 days), pre-starter II ( 22 to 35 days) and starter I (36 to 49 days) diets were supplemented as follows: control diet (CD): no plasma or yeast extract; plasma (PL) diet: addition of $6 \%, 4 \%$ and $2 \%$ plasma; yeast extract (YE) diet: addition of $6 \%, 4 \%$ and $2 \%$ yeast extract; plasma + yeast extract (PL+YE) diet: addition of $3 \%, 2 \%$ and $1 \%$ plasma and yeast extract each. From 50 to 63 days of age all piglets received the same diet. No difference in performance was observed from 7 to 21 days and from 7 to 28 days of age, whereas DWG was higher from 7 to 35 days in piglets receiving the PL+YE diet (268, 278, 271 and $288 \mathrm{~g}$ /day for CD, PL, YE and PL+YE, respectively). From 7 to 49 days and from 7 to 63 days, DWG (330 and $519 \mathrm{~g}$ /day, respectively) and DFI (307 and $647 \mathrm{~g} /$ day) were higher in animals receiving the PL-YE diet when compared with those consuming CD (DWG: 295 and 486 g/day; DFI: 266 and 594 g/day). No significant differences in intestinal morphology were observed between piglets receiving the different diets. The combination of plasma and yeast extract elevates DWG, but does not affect the intestinal morphology of piglets from 7 to 63 days of age.
\end{abstract}

Key Words: feed conversion, feed intake, swine, villi, weight gain

\section{Introduction}

At birth, the gastrointestinal tract of piglets is completely adapted to the digestion and utilization of the milk of their sow, with an apparent fat digestion of $96 \%$ during this phase (Jensen et al., 1997). However, important changes in the composition of the diet occur at weaning and require the presence of appropriate enzymes in the stomach, pancreas and intestine, which are usually not produced during the suckling period. As a consequence, weaning is associated with physiological and nutritional stress, which reduces feed intake and weight gain (Makkink et al., 1994).

The milk meets the energy requirements of piglets only until three weeks of age, a time when milk production by the sow reaches its peak and declines thereafter. In contrast, the energy requirements of piglets increase rapidly and supplementation is required to meet these demands. In this respect, two aspects need to be taken into account: the first concerns the variation in the quality and quantity of milk produced by the sow, and the second, particularities of the digestive system of piglets (Roppa, 1998).

When piglets are weaned at approximately three weeks of age, they no longer receive the immunoglobulins present in maternal milk that protect the small intestine (Wilson, 1974). This loss might be responsible for the growth delay normally seen in piglets that are weaned early, since the immune system only reaches its maturity at approximately six weeks of age (Stein, 1996).

In the small intestine, nutrients and water are absorbed by villus enterocytes, which are derived from crypt cells. A reduction in villous height $(\mathrm{VH})$ and an increase in crypt depth (CD) are related to changes in the number of enterocytes. Therefore, the shortening of villi predisposes to poor digestion and absorption, which may be involved in the pathogenesis of post-weaning diarrhea (Hampson, 1986).

The greater the villus size, the higher the capacity of nutrient digestion and absorption since various digestive 
enzymes are produced in the villous borders. However, a major reduction in villous size is observed at weaning, which seriously affects the villous structure; this reduction reaches 63\% within the first days (Roppa, 1998).

Dietary alternatives, as well as alternative ingredients or protein combinations, have been studied in an attempt to increase the feed intake of piglets before weaning and to improve diet quality and consequently animal performance (Ferreira, 1992).

The objective of the present study was to evaluate performance and intestinal morphology of piglets fed diets supplemented with plasma and/or yeast extract from 7 to 63 days of age.

\section{Material and Methods}

The experiment was conducted at the facilities of Granja Paraíso pig farm, located in Patos de Minas, Minas Gerais, Brazil. A total of 288 castrated male piglets (Agroceres PIC ${ }^{\circledR}$ genetics) were used. The animals were fed a dry diet throughout the experiment and were subjected to two periods of management: the first in the maternity unit and the second in the nursery after weaning.

At seven days of age with a starter body weight of $2.57 \pm 0.05 \mathrm{~kg}$, piglets were equally allocated to the experimental diets and maintained in maternity cages with sows of third and fourth production cycles until weaning at 21 days of age. At that time, the piglets were transferred to nursing pens $(1.60 \times 1.25 \times 1.65 \mathrm{~m})$ with a partially slatted floor and equipped with semi-automatic feeders and nipple drinkers. A randomized block design was used to control starter differences in body weight, consisting of four experimental diets, six repetitions and 12 piglets per experimental unit. The experiment was conducted over a period of eight weeks, including two weeks in the maternity unit and the last 6 weeks in the nursery.

The pre-starter I ( 7 to 21 days), pre-starter II ( 22 to 35 days) and starter I ( 36 to 49 days) diets were supplemented as follows: control diet: no plasma or yeast extract; plasma (PL) diet: addition of $6 \%, 4 \%$ and $2 \%$ plasma; yeast extract (YE) diet: addition of $6 \%, 4 \%$ and $2 \%$ yeast extract; plasma + yeast extract (PL+YE) diet: addition of 3\%, 2\% and $1 \%$ plasma and yeast extract each. From 50 to 63 days of age, all piglets received the same diet based on corn and soybean meal, which consisted of $3,260 \mathrm{kcal} / \mathrm{kg}$ metabolizable energy (ME), $20 \%$ crude protein (CP), $0.80 \% \mathrm{Ca}, 0.61 \%$ $\mathrm{Pt}, 1.23 \%$ lysine, $0.35 \%$ methionine, $0.81 \%$ threonine, and $0.23 \%$ tryptophan. The diets tested were formulated to meet the minimum nutritional requirements of piglets according to Rostagno et al. (2005) (Tables 1, 2 and 3).
Both piglets and sows (which were fed the routine farm ration) received feed and water ad libitum throughout the experiment. Maximum and minimum temperatures and relative air humidity were recorded twice a day, at $8 \mathrm{~h} 00$ and $17 \mathrm{~h} 00$ (Table 4). The piglets were weighed at 7, 21, 28, 35, 49 , and 63 days of age. Feed leftovers were weighed on the same occasions and used for the calculation of daily feed intake, daily weight gain and feed conversion.

For structural and ultrastructural analysis of duodenal and jejunal mucosa, 48 piglets with a live weight close the mean of each repetition were slaughtered at 28 and 49 days of age ( 7 and 28 days postweaning), corresponding to six

Table 1 - Percentage, nutritional and energetic compositions of pre-starter diets I supplied to piglets from 7 to 21 days of age

\begin{tabular}{|c|c|c|c|c|}
\hline \multirow[b]{2}{*}{ Ingredients } & \multicolumn{4}{|c|}{ Experimental diets } \\
\hline & $\begin{array}{c}\text { Control } \\
\text { diet }\end{array}$ & Plasma & $\begin{array}{c}\text { Yeast } \\
\text { extract }\end{array}$ & $\begin{array}{l}\text { Plasma } \\
+ \text { yeast } \\
\text { extract }\end{array}$ \\
\hline Corn, $7.8 \% \mathrm{CP}$ & 26.982 & 33.785 & 27.730 & 30.740 \\
\hline Soybean flour, $52 \% \mathrm{CP}$ & 12.000 & - & 6.000 & 3.650 \\
\hline Soybean meal, $45 \% \mathrm{CP}$ & 9.000 & 9.000 & 9.000 & 9.000 \\
\hline Yeast extract & - & - & 6.000 & 3.000 \\
\hline Cracker meal & 10.000 & 10.00 & 10.000 & 10.000 \\
\hline Bovine plasma & - & 6.000 & - & 3.000 \\
\hline Whey & 17.900 & 17.900 & 17.900 & 17.900 \\
\hline Bone meal, $16 \% \mathrm{CP}$ & 0.850 & 0.350 & 0.250 & 0.300 \\
\hline Sugar & 5.000 & 5.000 & 5.000 & 5.000 \\
\hline Pre-starter supplement $\mathrm{I}^{1}$ & 10.000 & 10.000 & 10.000 & 10.000 \\
\hline Pre-starter supplement II $^{1}$ & 5.000 & 5.000 & 5.000 & 5.000 \\
\hline Sodium bentonite & 0.300 & 0.300 & 0.300 & 0.300 \\
\hline Degummed soybean oil & 2.950 & 2.650 & 2.800 & 2.100 \\
\hline DL-methionine 99-MI & - & - & 0.005 & - \\
\hline L-lysine 80-MI & 0.015 & 0.015 & 0.015 & 0.010 \\
\hline L-threonine $98 \%$ & 0.003 & - & - & - \\
\hline Total, kg & 100.000 & 100.000 & 100.000 & 100.000 \\
\hline \multicolumn{5}{|l|}{ Nutritional levels ${ }^{2}$} \\
\hline Metabolizable energy, $\mathrm{kcal} / \mathrm{kg}$ & 3,500 & 3,500 & 3,500 & 3,500 \\
\hline Crude protein, $\%$ & 19.53 & 18.10 & 19.50 & 18.91 \\
\hline Total lactose, $\%$ & 16.00 & 16.00 & 16.00 & 16.00 \\
\hline Fat, $\%$ & 7.11 & 6.25 & 6.91 & 6.35 \\
\hline Crude fiber, $\%$ & 1.81 & 1.59 & 1.67 & 1.75 \\
\hline Calcium, $\%$ & 0.85 & 0.64 & 0.68 & 0.67 \\
\hline Total phosphorus, $\%$ & 0.65 & 0.62 & 0.62 & 0.62 \\
\hline Available phosphorus, $\%$ & 0.52 & 0.52 & 0.52 & 0.52 \\
\hline Sodium, $\%$ & 0.39 & 0.55 & 0.40 & 0.48 \\
\hline Total lysine, $\%$ & 1.63 & 1.61 & 1.64 & 1.63 \\
\hline Digestible lysine, \% & 1.50 & 1.50 & 1.50 & 1.50 \\
\hline Total methionine, $\%$ & 0.61 & 0.60 & 0.61 & 0.60 \\
\hline Digestible methionine, $\%$ & 0.58 & 0.58 & 0.58 & 0.58 \\
\hline Total methionine + cystine, $\%$ & 0.92 & 0.94 & 0.90 & 0.92 \\
\hline Digestible methionine + cystine, $\%$ & 0.85 & 0.87 & 0.86 & 0.85 \\
\hline Total threonine, $\%$ & 1.05 & 1.06 & 1.06 & 1.07 \\
\hline Digestible threonine, $\%$ & 0.96 & 0.96 & 0.95 & 0.95 \\
\hline Total tryptophan, $\%$ & 0.26 & 0.25 & 0.25 & 0.25 \\
\hline Digestible tryptophan, \% & 0.22 & 0.22 & 0.22 & 0.22 \\
\hline
\end{tabular}

${ }^{1}$ Guaranteed levels per kg of diet: vit. A - 4,000 IU; vit. D3 - 220 IU; vit. E - 22 mg; vit. $\mathrm{K}-0.5 \mathrm{mg}$; vit B2 - $3.75 \mathrm{mg}$; vit. B12 - $20 \mathrm{mcg}$; calcium pantothenate $-12 \mathrm{mg}$; niacin - $20 \mathrm{mg}$; choline - $60 \mathrm{mg}$; iodine - $140 \mathrm{mg}$; selenium - $300 \mathrm{mg}$; manganese - $10 \mathrm{mg}$; zinc - $100 \mathrm{mg}$; copper - $10 \mathrm{mg}$; iron - $99 \mathrm{mg}$.

${ }^{2}$ Nutritional values of ingredients, as proposed by Rostagno et al. (2005).

$\mathrm{CP}$ - crude protein. 
animals per treatment/slaughter. For slaughter, the animals were stunned electrically and then subjected to cardiac perfusion and bleeding. Next, the viscera were removed and two segments of $1 \mathrm{~cm}$ each were collected from the two parts of the small intestine (duodenum and jejunum).

For structural analysis of the small intestine, samples $( \pm 3 \mathrm{~cm})$ from the duodenum and mid-portion of the jejunum were opened along the mesenteric border and collected. The specimens were fixed in Bouin fixative for 24 hours. After this period, the specimens were washed in running water and in $70 \%$ ethanol for removal of the fixative, dehydrated in an increasing alcohol series (70 to $100 \%$ ), cleared in

Table 2 - Percentage, nutritional and energetic compositions of pre-starter diets II supplied to piglets from 22 to 35 days of age

\begin{tabular}{|c|c|c|c|c|}
\hline \multirow[b]{2}{*}{ Ingredients } & \multicolumn{4}{|c|}{ Experimental diets } \\
\hline & $\begin{array}{c}\text { Control } \\
\text { diet }\end{array}$ & Plasma & $\begin{array}{c}\text { Yeast } \\
\text { extract }\end{array}$ & $\begin{array}{l}\text { Plasma } \\
+ \text { yeast } \\
\text { extract }\end{array}$ \\
\hline Corn, $7.8 \% \mathrm{CP}$ & 39.943 & 42.915 & 41.130 & 40.870 \\
\hline Soybean flour, $52 \% \mathrm{CP}$ & 8.280 & 2.5000 & 3.300 & 3.975 \\
\hline Soybean meal, $45 \%$ CP & 12.000 & 12.000 & 12.000 & 12.000 \\
\hline Yeast extract & - & - & 4.000 & 2.000 \\
\hline Cracker meal & 7.000 & 7.000 & 7.000 & 7.000 \\
\hline Bovine plasma & - & 4.000 & - & 2.000 \\
\hline Whey & 14.140 & 14.150 & 14.100 & 14.150 \\
\hline Bone meal, $16 \% \mathrm{CP}$ & 0.850 & 0.700 & 0.600 & 0.650 \\
\hline Sugar & 5.000 & 5.000 & 5.000 & 5.000 \\
\hline Pre-starter supplement II $^{1}$ & 10.000 & 10.000 & 10.000 & 10.000 \\
\hline Sodium bentonite & 0.300 & 0.300 & 0.300 & 0.300 \\
\hline Degummed soybean oil & 2.320 & 1.420 & 2.300 & 2.975 \\
\hline DL-methionine 99-MI & 0.022 & - & 0.050 & 0.010 \\
\hline L-lysine 80-MI & 0.095 & 0.015 & 0.150 & 0.050 \\
\hline L-threonine $98 \%$ & 0.050 & - & 0.070 & 0.020 \\
\hline Total, kg & 100.000 & 100.000 & 100.000 & 100.000 \\
\hline \multicolumn{5}{|l|}{ Nutritional levels ${ }^{2}$} \\
\hline Metabolizable energy, $\mathrm{kcal} / \mathrm{kg}$ & 3,450 & 3,450 & 3,450 & 3,450 \\
\hline Crude protein, $\%$ & 18.00 & 18.00 & 17.37 & 18.00 \\
\hline Total lactose, $\%$ & 12.00 & 12.00 & 12.00 & 12.00 \\
\hline Fat, \% & 6.44 & 5.65 & 6.39 & 6.12 \\
\hline Crude fiber, $\%$ & 2.02 & 1.91 & 2.00 & 2.02 \\
\hline Calcium, $\%$ & 0.76 & 0.70 & 0.70 & 0.70 \\
\hline Total phosphorus, $\%$ & 0.64 & 0.66 & 0.64 & 0.65 \\
\hline Available phosphorus, $\%$ & 0.50 & 0.53 & 0.52 & 0.52 \\
\hline Sodium, $\%$ & 0.31 & 0.43 & 0.32 & 0.37 \\
\hline Total lysine, $\%$ & 1.52 & 1.52 & 1.52 & 1.52 \\
\hline Digestible lysine, $\%$ & 1.40 & 1.40 & 1.40 & 1.40 \\
\hline Total methionine, $\%$ & 0.59 & 0.58 & 0.60 & 0.59 \\
\hline Digestible methionine, $\%$ & 0.56 & 0.56 & 0.57 & 0.56 \\
\hline Total methionine + cystine, $\%$ & 0.88 & 0.89 & 0.88 & 0.88 \\
\hline Digestible methionine + cystine, $\%$ & 0.81 & 0.82 & 0.81 & 0.81 \\
\hline Total threonine, $\%$ & 0.99 & 1.00 & 0.99 & 0.99 \\
\hline Digestible threonine, $\%$ & 0.88 & 0.89 & 0.88 & 0.88 \\
\hline Total tryptophan, $\%$ & 0.20 & 0.20 & 0.20 & 0.20 \\
\hline Digestible tryptophan, $\%$ & 0.18 & 0.18 & 0.18 & 0.18 \\
\hline
\end{tabular}

xylene and embedded in paraffin. The blocks were cut into $5 \mu \mathrm{m}$ thick sections with a microtome, generating 12 to 14 semi-serial sections of each segment per animal. The sections were stained with hematoxylin-eosin.

The histological slides were examined under an Olympus BX41 light microscope equipped with an Olympus DP11-N digital camera. The images were analyzed with the Image Pro-Plus ${ }^{\circledR} 4.1$ program at a magnification of $125 \times$ for the evaluation of villus height ( $\mathrm{VH})$ and crypt depth (CD). Thirty measurements of each variable were made per sample and the mean was used for analysis. Based on these results, the $\mathrm{VH} / \mathrm{CD}$ ratio was calculated.

Table 3 - Percentage, nutritional and energetic compositions of starter diets I supplied to piglets from 36 to 49 days of age

\begin{tabular}{lcccc}
\hline & \multicolumn{4}{c}{ Experimental diets } \\
\cline { 2 - 5 } Ingredients & $\begin{array}{c}\text { Control } \\
\text { diet }\end{array}$ & Plasma & $\begin{array}{c}\text { Yeast } \\
\text { extract }\end{array}$ & $\begin{array}{c}\text { Plasma } \\
+ \text { yeast } \\
\text { extract }\end{array}$ \\
\hline Corn, 7.8\% CP & 48.160 & 49.585 & 47.910 & 48.530 \\
Soybean flour, 52\% CP & 6.250 & 3.200 & 4.500 & 4.000 \\
Soybean meal, 45\% CP & 18.000 & 18.000 & 18.000 & 18.000 \\
Yeast extract & - & - & 2.000 & 1.000 \\
Cracker meal & 7.000 & 7.000 & 7.000 & 7.000 \\
Bovine plasma & - & 2.000 & - & 1.000 \\
Whey & 9.720 & 9.720 & 9.700 & 9.650 \\
Bone meal, 16\% CP & 0.550 & 0.550 & 0.500 & 0.500 \\
Sugar & 2.000 & 2.000 & 2.000 & 2.000 \\
Starter supplement I & 5.000 & 5.000 & 5.000 & 5.000 \\
Sodium bentonite & 0.300 & 0.300 & 0.300 & 0.300 \\
Degummed soybean oil & 2.900 & 2.480 & 2.980 & 3.015 \\
DL-methionine 99-MI & 0.040 & 0.025 & 0.050 & 0.002 \\
L-lysine 80-MI & 0.010 & 0.100 & - & - \\
L-threonine 98\% & 0.070 & 0.040 & 0.060 & 0.003 \\
Total, kg & 100.000 & 100.000 & 100.000 & 100.000
\end{tabular}

Nutritional levels ${ }^{2}$

Metabolizable energy, $\mathrm{kcal} / \mathrm{kg} \quad 3,400 \quad 3,400 \quad 3,400 \quad 3,400$

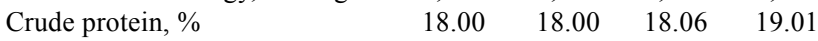

$\begin{array}{lllll}\text { Total lactose, } \% & 7.00 & 7.00 & 7.00 & 7.00\end{array}$

Fat, \% $6.36 \quad 6.00 \quad 6.41 \quad 6.44$

$\begin{array}{lllll}\text { Crude fiber, \% } & 2.44 & 2.38 & 2.39 & 2.49\end{array}$

$\begin{array}{lllll}\text { Calcium, \% } & 0.70 & 0.70 & 0.70 & 0.70\end{array}$

Total phosphorus, \% $\quad 0.59 \quad 0.61 \quad 0.60 \quad 0.61$

Available phosphorus, \% $\quad \begin{array}{lllll}0.42 & 0.44 & 0.44 & 0.44\end{array}$

$\begin{array}{lllll}\text { Sodium, \% } & 0.28 & 0.34 & 0.28 & 0.31\end{array}$

$\begin{array}{lllll}\text { Total lysine, \% } & 1.42 & 1.42 & 1.42 & 1.42\end{array}$

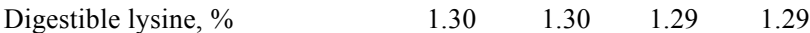

$\begin{array}{lllll}\text { Total methionine, \% } & 0.55 & 0.54 & 0.55 & 0.54\end{array}$

Digestible methionine, \% $\quad 0.52 \quad 0.51 \quad 0.52 \quad 0.51$

$\begin{array}{lllll}\text { Total methionine }+ \text { cystine, } \% & 0.84 & 0.84 & 0.84 & 0.84\end{array}$

Digestible methionine + cystine, $\% \quad 0.77 \quad 0.77 \quad 0.77 \quad 0.77$

$\begin{array}{lllll}\text { Total threonine, } \% & 0.94 & 0.94 & 0.94 & 0.95\end{array}$

Digestible threonine, \% $\quad 0.83 \quad 0.83 \quad 0.83 \quad 0.83$

$\begin{array}{lllll}\text { Total tryptophan, \% } & 0.20 & 0.21 & 0.20 & 0.21\end{array}$

$\begin{array}{lllll}\text { Digestible tryptophan, \% } & 0.17 & 0.18 & 0.17 & 0.18\end{array}$

${ }^{1}$ Guaranteed levels per kg of diet: vit. A - 4,000 IU; vit. D3 - 220 IU; vit. E - $22 \mathrm{mg}$; vit. K - $0.5 \mathrm{mg}$; vit B2 - $3.75 \mathrm{mg}$; vit. B12 - $20 \mathrm{mcg}$; calcium pantothenate - $12 \mathrm{mg}$; niacin - $20 \mathrm{mg}$; choline - $60 \mathrm{mg}$; iodine - $140 \mathrm{mg}$; selenium - $300 \mathrm{mg}$; manganese - $10 \mathrm{mg}$; zinc - $100 \mathrm{mg}$; copper - $10 \mathrm{mg}$; iron - $99 \mathrm{mg}$.

${ }^{2}$ Nutritional values of ingredients, as proposed by Rostagno et al. (2005).

$\mathrm{CP}$ - crude protein. 
Table 4 - Average maximum and minimum temperature and relative humidity and their respective standard deviations recorded during the experimental period

\begin{tabular}{lccc}
\hline \multirow{2}{*}{ Period } & \multicolumn{2}{c}{ Temperatures $\left({ }^{\circ} \mathrm{C}\right)$} & $\begin{array}{c}\text { Relative humidity } \\
(\%)\end{array}$ \\
\cline { 2 - 3 } & Maximum & Minimum & $64.8 \pm 9.2$ \\
$08 \mathrm{~h} 00$ & $27.3 \pm 3.5$ & $14.7 \pm 2.8$ & $38.1 \pm 17.3$ \\
\hline
\end{tabular}

Samples $( \pm 1 \mathrm{~cm})$ were also collected from the duodenum and mid-portion of the jejunum for ultrastructural analysis of the small intestine, immediately washed in phosphate buffer (0.1 M, pH 7.4) and fixed in glutaraldehyde. Next, the specimens were dehydrated in an increasing ethanol series, critical point dried with $\mathrm{CO}_{2}$, mounted, coated with gold-palladium and examined under a JEOL JSM scanning electron microscope operated at $15 \mathrm{kV}$. Electron micrographs were obtained from five areas per sample for the estimation of villus density (number of villi $/ \mu \mathrm{m}^{2}$ ). The microscopic analyses were performed at the laboratories of the Department of Morphology and Animal Physiology, Faculty of Agricultural and Veterinary Sciences, Unesp, Campus Jaboticabal, Brazil.

Statistical analysis was performed using the SAEG (Sistema para Análises Estatísticas e Genéticas, version 8.0) software. The data were analyzed by analysis of variance and treatment means were compared by the StudentNewman-Keuls test, adopting a significance level of $5 \%$. The assumptions for analysis of variance were tested.

\section{Results and Discussion}

No significant effects $(\mathrm{P}>0.05)$ of the different experimental diets on daily weight gain, daily feed intake or feed conversion of piglets were observed between 7 and 21 days of age (Table 5). These results agree with Carlson \& Veum (2000), who also found no effect of the addition of plasma (5\%) and yeast extract (5\%) on these variables in piglets from 7 to 21 days of age. In contrast, Ferreira et al. (1992) showed that offering complex diets by day 7 or day 10 after birth stimulates the development of the digestive enzyme system, improving utilization of the diets.

Feed intake shows marked individual variations during the suckling period as a result of competition between piglets with their littermates for sow milk (Appleby et al., 1991). Pajor et al. (1991) reported variations in preweaning feed intake of 13 to $191 \mathrm{~g} /$ piglet between day 10 and day 28 of age when the animals were weaned. The feed intake of piglets until 21 days of age might be a limiting factor for subsequent performance. In a literature review of studies on animals fed solid diets, Lopes et al. (1986) found a feed intake of less than $10 \mathrm{~g} / \mathrm{piglet} / \mathrm{day}$ during the suckling period.

The different experimental diets did not affect $(\mathrm{P}>0.05)$ daily weight gain, daily feed intake or feed conversion of piglets between 7 and 28 days of age (Table 5). The low feed intake after weaning is one of the main factors associated with intestinal atrophy. Any component included in the starter diets that improves consumption during this period will also improve digestion and intestinal absorption. Daily weight gain and feed intake tended to increase in animals receiving diets containing plasma and/or yeast extract, but this difference was not significant $(\mathrm{P}>0.05)$ (Table 5).

Piglets receiving the PL+YE diet showed higher daily weight gain than animals fed the control and YE diets between 7 and 35 days of age $(\mathrm{P}<0.05)$ (Table 5). These results disagree with those reported by Costa (2006), who found no effect of complex diets on the daily weight gain of piglets at 35 days of age. Neither daily feed intake nor feed conversion was affected by the experimental diets during this period $(\mathrm{P}>0.05)$. In contrast, Hansen et al. (1993) and Kats et al. (1994) observed higher daily feed intake by piglets consuming complex diets when compared with animals receiving the control diet.

Table 5 - Average daily weight gain (DWG), daily feed intake (DFI) and feed conversion (FC) of piglets in different periods fed different experimental diets

\begin{tabular}{lcccccc}
\hline & \multicolumn{7}{c}{ Experimental diets } & & \\
\cline { 2 - 4 } & $\begin{array}{c}\text { Control } \\
\text { diet }\end{array}$ & Plasma & $\begin{array}{c}\text { Yeast } \\
\text { extract }\end{array}$ & $\begin{array}{c}\text { Plasma }+ \\
\text { yeast extract }\end{array}$ & & CV (\%) \\
\hline Period 1 & & & & & & \\
DWG (g) & 317 & 322 & 326 & 324 & 0.1893 & 9.84 \\
DFI (g) & 44 & 45 & 46 & 46 & 0.3665 & 6.00 \\
FC & 0.14 & 0.14 & 0.14 & 0.14 & 0.4893 & 5.43 \\
Period 2 & & & & & & \\
DWG (g) & 238 & 249 & 250 & 251 & 0.3626 & 5.90 \\
DFI (g) & 65 & 69 & 69 & 71 & 0.3993 & 9.36 \\
FC & 0.27 & 0.28 & 0.28 & 0.28 & 0.4156 & 10.49 \\
Period 3 & & & & & & \\
DWG (g) & $268 \mathrm{~b}$ & $278 \mathrm{ab}$ & $271 \mathrm{~b}$ & $288 \mathrm{a}$ & 0.0129 & 3.46 \\
DFI (g) & 154 & 167 & 156 & 169 & 0.2163 & 9.34 \\
FC & 0.57 & 0.60 & 0.57 & 0.59 & 0.3452 & 7.82 \\
Period 4 & & & & & & \\
DWG (g) & $295 \mathrm{c}$ & $319 \mathrm{ab}$ & $310 \mathrm{~b}$ & $330 \mathrm{a}$ & 0.0002 & 3.46 \\
DFI (g) & $266 \mathrm{c}$ & $295 \mathrm{ab}$ & $283 \mathrm{bc}$ & $307 \mathrm{a}$ & 0.0029 & 5.70 \\
FC & 0.90 & 0.92 & 0.91 & 0.93 & 0.3962 & 4.23 \\
Period 5 & & & & & & \\
DWG (g) & $486 \mathrm{c}$ & $502 \mathrm{~b}$ & $501 \mathrm{~b}$ & $519 \mathrm{a}$ & 0.0006 & 2.14 \\
DFI (g) & $594 \mathrm{~b}$ & $627 \mathrm{ab}$ & $622 \mathrm{ab}$ & $647 \mathrm{a}$ & 0.0170 & 4.11 \\
FC & 1.22 & 1.25 & 1.24 & 1.24 & 0.3526 & 3.34 \\
\hline
\end{tabular}

Means followed by the same letter within the row are similar by the SNK test $(5 \%)$. Period 1 - from 7 to 21 days of age; Period 2 - from 7 to 28 days of age; Period 3 - from 7 to 35 days of age; Period 4 - from 7 to 49 days of age; Period 5 - from 7 to 63 days of age.

$\mathrm{CV}$ - coefficient of variation. 
From 7 to 49 days of age, daily weight gain was higher in piglets receiving the $\mathrm{PL}+\mathrm{YE} \operatorname{diet}(\mathrm{P}<0.05)$ and lower in those receiving the control diet $(\mathrm{P}<0.05)$. Daily feed intake was higher in piglets fed the PL+YE diet as compared with those receiving the control and $\mathrm{YE}$ diets $(\mathrm{P}<0.05)$. Piglets fed the YE and PL diets presented similar daily feed intake. The lowest daily feed intake, in absolute values, was observed in piglets fed the control diet, which did not differ from animals consuming the YE diet. Feed conversion was not affected by the different experimental diets $(\mathrm{P}>0.05)$ (Table 5). These results disagree with Costa (2006), who observed higher daily weight gain and feed intake during this period in piglets fed plasma-supplemented diets compared with those receiving diets containing yeast extract. The author also found no effects of the diets on feed conversion.

Daily weight gain from 7 to 63 days of age was higher in piglets receiving the $\mathrm{PL}+\mathrm{YE}$ diet than in those fed the $\mathrm{PL}$ and $\mathrm{YE}$ diets $(\mathrm{P}<0.05)$ and the lowest gain was observed in animals fed the control diet $(\mathrm{P}<0.05)$. Daily feed intake was higher in piglets receiving the $\mathrm{PL}+\mathrm{YE} \operatorname{diet}(\mathrm{P}<0.05)$ in relation to animals fed the control diet. No significant difference in daily feed intake was observed between piglets fed the YE or PL diets and those receiving the control diet, although feed intake was $5.26 \%$ and $4.5 \%$ lower in the latter as compared with piglets fed the PL and YE diets, respectively. Feed conversion was not affected by the experimental diets $(\mathrm{P}>0.05)$.

The results of this experiment agree with those reported by Carlson \& Veum (2000), who evaluated the effects of the addition of plasma (5\%) and/or yeast extract (5\%) to piglet diets during the starter phase and observed better performance of animals fed the diet containing both additives. In addition, the authors reported that weight gain, feed intake and feed conversion efficiency were similar in animals receiving the plasma- or yeast extractsupplemented diets.

The present results suggest that the combined administration of protein sources (YE and PL) favor the daily feed intake of piglets during the postweaning period, with a positive effect on daily weight gain. Since the diets were isonutrient, the beneficial effects observed for the diets supplemented with PL and YE alone or in combination were related to factors present in these ingredients that are not essential nutrients for the formulation of a diet. No disease or death of piglets was observed during the experimental period. In addition, the animals presented no diarrhea or loose stool and no signs or symptoms of enteritis.

No significant differences $(\mathrm{P}>0.05)$ in $\mathrm{VH}, \mathrm{CD}$ or $\mathrm{VH} / \mathrm{CD}$ ratio in the duodenum and jejunum were observed between piglets receiving the different experimental diets and slaughtered at 28 days of age (Table 6). These results agree with the study of Bertol (2000) and Castillo (2004), who found no effects of different protein sources on $\mathrm{VH}, \mathrm{CD}$ or $\mathrm{VH} / \mathrm{CD}$ ratio. Jiang et al. (2000) also observed no effect of diets supplemented with plasma on the same jejunal variables in piglets slaughtered at 8 days postweaning. Similarly, the addition of $15 \%$ plasma or casein exerted no effect on jejunal $\mathrm{VH}$ or $\mathrm{CD}$ in piglets slaughtered at 28 days of age (Dijk et al., 2001). Carlson \& Veum (2000) also found no effect of the addition of plasma or yeast extract on duodenal or jejunal $\mathrm{VH}$ in piglets slaughtered at 28 days of age. However, in that study CD was lower and the VH/CD ratio tended to be higher in piglets fed diets supplemented with plasma and yeast extract as compared with those receiving the control diets without either ingredient. The present results disagree with those reported by Domeneghini et al. (2004), who evaluated diets supplemented with $0.05 \%$ nucleotides and observed a higher $\mathrm{VH}$ and $\mathrm{VH} / \mathrm{CD}$ ratio and lower $\mathrm{CD}$ in piglets slaughtered at 28 days of age.

According to Hancock (1990), CD is an indicator of the degree of epithelial cell hyperplasia, which is related to antigenicity of the diet, among other factors. A lower $\mathrm{CD}$ indicates less aggression of the diet to the morphology of the intestinal wall (Li et al., 1991). In addition, a higher $\mathrm{VH} / \mathrm{CD}$ ratio indicates a greater capacity of digestion and absorption by intestinal villi, thus demonstrating the positive effect of plasma and yeast extract on the intestinal wall of piglets.

Experimental diets did not affect $(\mathrm{P}>0.05) \mathrm{VH}, \mathrm{CD}$ or $\mathrm{VH} / \mathrm{CD}$ ratio of piglets slaughtered at 49 days of age (Table 6 ). These results disagree with those reported by Cera et al. (1988), Makkink et al. (1994), McCracken et al. (1999) and Klurfeld (2002), who demonstrated a significant effect of total nutrient intake on gastrointestinal tract development; VH was directly related to dry matter and energy intake.

Immunoglobulins, peptides and specific amino acids present in plasma are among the nutrients that stimulate the development of intestinal villi; immunoglobulins are the main component responsible for the beneficial effects of plasma. However, the absorption of intact protein after weaning is unlikely and the favorable effects of plasma seem to be more related to peptides released by hydrolysis of proteins present in the immunoglobulin fraction and/or specific amino acids released by total protein hydrolysis, which stimulate intestinal enterocytes.

Dietary nucleotides enhance the growth and maturation of intestinal epithelial cells as demonstrated by an increase in mucosal protein and DNA synthesis, increased $\mathrm{VH}$ in the small intestine, and increased activity of maltase and 
lactase (Uauy et al., 1990; Carver, 1994). In addition, dietary nucleotides also stimulate cell differentiation (Sanderson \& He, 1994) and dietary supplementation with nucleic acid stimulates mucosal cell proliferation (Kishibuchi et al., 1997; Tsujinaka et al., 1999). The development of the gastrointestinal tract directly affects the digestion and absorption of nutrients and, consequently, animal performance. In view of the effects of nucleotides on the maintenance and maturation of the intestinal mucosa, their presence in the diet seems to be important for structural maintenance and growth of the gastrointestinal tract, particularly after weaning.

According to Hall \& Byrne (1989), the decrease in the rate of crypt cell production and consequent villous atrophy is the result of deficient energy and protein intake. Hancock (1990) and Li et al. (1991) concluded that there is a positive correlation between $\mathrm{VH}$ in the small intestine and the growth rate of piglets.

At 28 days of age, villus density in the duodenum was not affected by the experimental diets $(\mathrm{P}>0.05)$ (Table 7), whereas in the jejunum this variable was higher in piglets receiving the $\mathrm{PL}+\mathrm{YE}$ diet than in those fed the control diet $(\mathrm{P}<0.05)$. These results agree with Cera et al. (1988), who observed visible alterations in the intestinal villi of piglets after weaning, which were influenced by the nutrients and protein sources used in the diets.

No effects of the experimental diets were observed on duodenum or jejunum villus density in piglets slaughtered

Table 6 - Average villus height (VH), crypt depth (CD) in $\mu \mathrm{m}$, and $\mathrm{VH} / \mathrm{CD}$ ratio in the duodenum and jejunum of piglets slaughtered at 28 and 49 days of age fed different experimental diets

\begin{tabular}{|c|c|c|c|c|c|c|}
\hline & \multicolumn{4}{|c|}{ Experimental diets } & \multirow[b]{2}{*}{$\mathrm{P}$} & \multirow[b]{2}{*}{$\mathrm{CV}(\%)$} \\
\hline & $\begin{array}{c}\text { Control } \\
\text { diet }\end{array}$ & Plasma & $\begin{array}{c}\text { Yeast } \\
\text { extract }\end{array}$ & $\begin{array}{l}\text { Plasma } \\
+ \text { yeast } \\
\text { extract }\end{array}$ & & \\
\hline \multicolumn{7}{|c|}{ Duodenum, 28 days } \\
\hline Villus height & 450.65 & 480.35 & 474.15 & 489.35 & 0.0980 & 5.47 \\
\hline Crypt depth & 196.65 & 210.50 & 201.35 & 201.15 & 0.1235 & 8.82 \\
\hline $\mathrm{VH} / \mathrm{CD}$ & 2.31 & 2.30 & 2.36 & 2.43 & 0.1198 & 9.90 \\
\hline \multicolumn{7}{|c|}{ Jejunum, 28 days } \\
\hline Villus height & 438.50 & 449.15 & 446.35 & 482.65 & 0.1052 & 6.85 \\
\hline Crypt depth & 175.00 & 182.85 & 176.85 & 188.85 & 0.1458 & 14.98 \\
\hline $\mathrm{VH} / \mathrm{CD}$ & 2.59 & 2.50 & 2.54 & 2.61 & 0.1236 & 18.46 \\
\hline \multicolumn{7}{|c|}{ Duodenum, 49 days } \\
\hline Villus height & 510.35 & 548.35 & 542.00 & 550.15 & 0.1401 & 5.89 \\
\hline Crypt depth & 175.15 & 183.50 & 181.00 & 187.00 & 0.1369 & 11.48 \\
\hline $\mathrm{VH} / \mathrm{CD}$ & 2.92 & 3.00 & 3.01 & 2.97 & 0.0985 & 6.09 \\
\hline \multicolumn{7}{|c|}{ Jejunum, 49 days } \\
\hline Villus height & 498.65 & 526.65 & 520.35 & 539.35 & 0.3316 & 7.24 \\
\hline Crypt depth & 170.15 & 178.00 & 171.15 & 173.15 & 0.1856 & 13.16 \\
\hline $\mathrm{VH} / \mathrm{CD}$ & 2.95 & 3.00 & 3.06 & 3.15 & 0.1125 & 10.87 \\
\hline
\end{tabular}

$\mathrm{CV}$ - coefficient of variation. at 49 days of age $(\mathrm{P}>0.05)$ (Table 7). According to Argenzio (1984), the pleats or folds increase the absorption surface by 10 times, villi by 150 times, and microvilli by 600 times.

Analysis of the electron micrographs of the duodenum of piglets slaughtered at 28 days of age and fed the control diet showed slight villous flattening without uniformity (Figure 1), indicating that the dietary nutrients were poorly utilized by the animals as compared with the other groups. However, since the first week after weaning is considered to be critical for piglets, none of the animals presented perfect villi. In contrast, ultrastructural analysis revealed major villous alterations in the jejunum of piglets slaughtered at 28 days of age (Figure 2). The villi were slightly thinned at the tips and markedly damaged in animals receiving the control and PL diets, whereas intact and finger-like villi were observed in the intestinal mucosa of piglets fed the $\mathrm{YE}$ and PL+YE diets, demonstrating greater preservation and maintenance of the intestinal epithelium.

At 49 days of age, deformation of the villous surface of the duodenum characterized by tongue-shaped villi and the occurrence of fusions was noted mainly in piglets fed the control diet (Figure 3). Finger-like villi that were visually more intact were observed in piglets receiving the other diets, indicating the preservation of villous integrity and a greater capacity of digestion and absorption. Analysis of the jejunum of piglets slaughtered at 49 days of age (Figure 4) showed tongue-shaped and compressed villi in animals receiving the PL, YE and PL+YE diets, whereas shorter and more flattened villi were observed in animals fed the control diet, indicating poor utilization of dietary nutrients.

Taken together, the results regarding performance of piglets and structural and ultrastructural analysis of the duodenum and jejunum suggest that the PL+YE diet was the best, followed by the PL and YE diets, whereas the control diet exerted the worst effect on animal performance and intestinal morphology.

Table 7 - Means for the density of villi $\left(\right.$ no. $\left./ \mu \mathrm{m}^{2}\right)$ in duodenum and jejunum of piglets at 28 and 49 days of age fed different experimental diets

\begin{tabular}{|c|c|c|c|c|c|c|}
\hline & \multicolumn{4}{|c|}{ Experimental diets } & \multirow[b]{2}{*}{$\mathrm{P}$} & \multirow[b]{2}{*}{$\mathrm{CV}(\%)$} \\
\hline & $\begin{array}{c}\text { Control } \\
\text { diet }\end{array}$ & Plasma & $\begin{array}{c}\text { Yeast } \\
\text { extract }\end{array}$ & $\begin{array}{l}\text { Plasma } \\
+ \text { yeast } \\
\text { extract }\end{array}$ & & \\
\hline \multicolumn{7}{|l|}{28 days } \\
\hline Duodenum & 79.00 & 76.95 & 65.85 & 77.65 & 0.1253 & 21.89 \\
\hline Jejunum & $63.50 \mathrm{~b}$ & $76.35 \mathrm{ab}$ & $73.15 \mathrm{ab}$ & $88.35 \mathrm{a}$ & 0.0493 & 18.69 \\
\hline \multicolumn{7}{|l|}{49 days } \\
\hline Duodenum & 36.00 & 44.50 & 40.50 & 45.65 & 0.1433 & 15.52 \\
\hline Jejunum & 50.85 & 54.50 & 54.15 & 56.35 & 0.1056 & 17.42 \\
\hline
\end{tabular}

$\mathrm{CV}$ - coefficient of variation. 

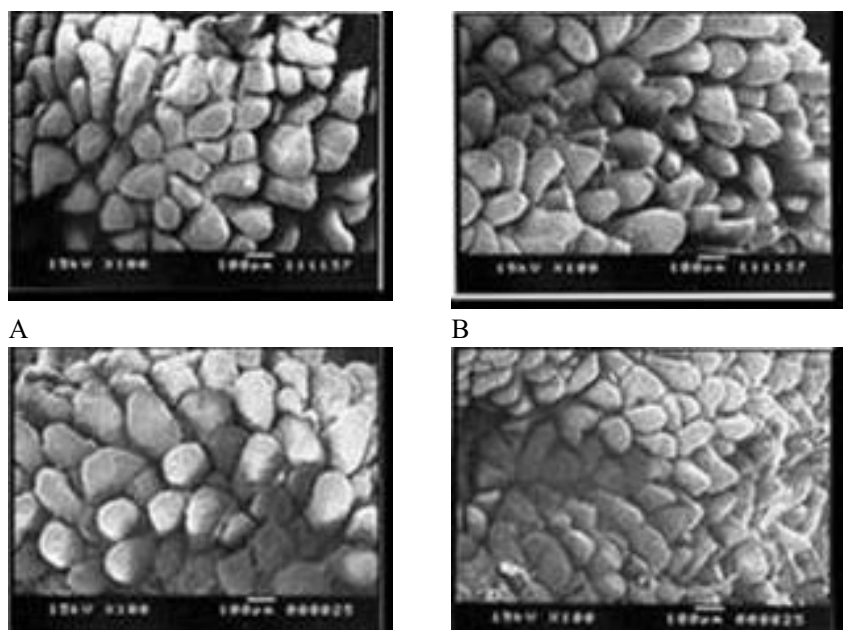

$\mathrm{C}$

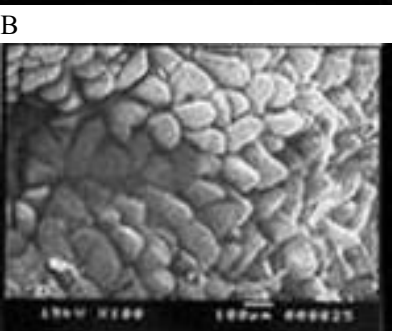

$\mathrm{D}$

$\mathrm{A}=150 \mathrm{X}$

Figure 1 - Electron-micrographs of duodenum of piglets slaughtered at 28 days of age and fed the control (A), plasma (B), yeast extract (C) and plasma + yeast extract (D) diets.
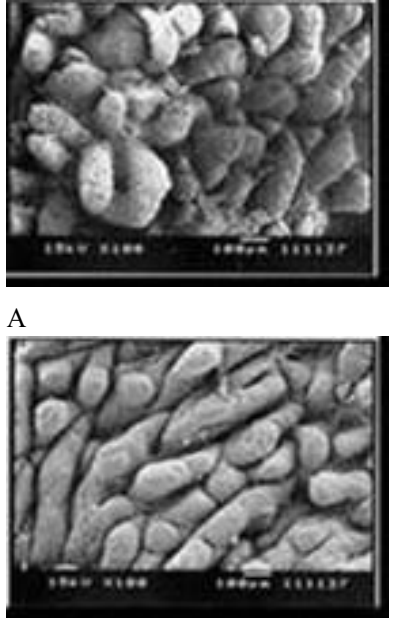

c

$\mathrm{A}=150 \mathrm{X}$

Figure 3 - Electron-micrographs of duodenum of piglets slaughtered at 49 days of age and fed control (A), plasma (B), yeast extract $(\mathrm{C})$ and plasma + yeast extract (D) diets.

\section{Conclusions}

The addition of plasma or yeast extract to pre- and postweaning diets has beneficial effects on the daily weight gain of piglets. Plasma and yeast extract exert a synergistic effect, favoring daily weight gain in piglets from 7 to 63 days of age. In general, the addition of plasma and/or yeast extract does not alter the structure and ultrastructure of the small intestine of piglets during the starter phase.

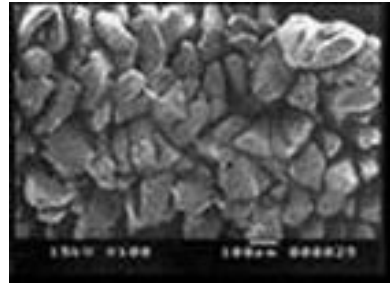

A

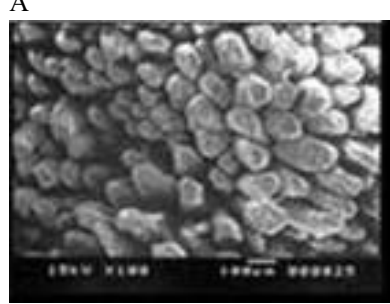

c

$\mathrm{A}=150 \mathrm{X}$.

Figure 2 - Electron-micrographs of jejunum of piglets slaughtered at 28 days of age and fed control (A), plasma (B), yeast extract $(\mathrm{C})$ and plasma + yeast extract (D) diets.

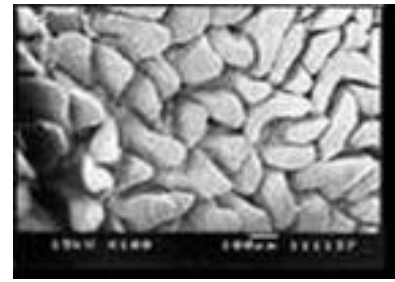

A

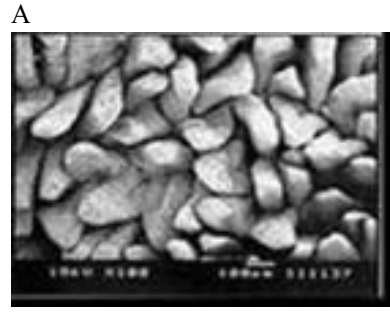

$\mathrm{C}$

$\mathrm{A}=150 \mathrm{X}$.

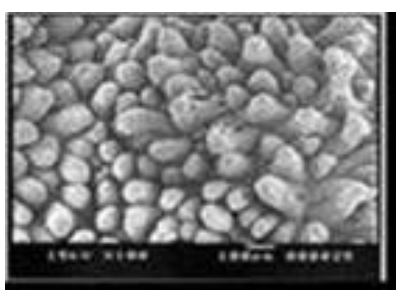

B

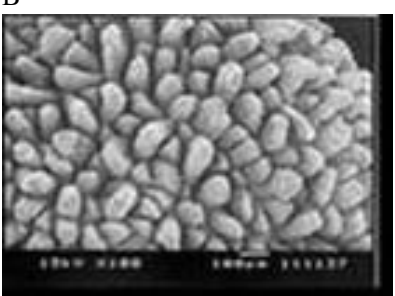

$\mathrm{D}$
Figure 4 - Electron-micrographs of jejunum of piglets slaughtered at 49 days of age and fed control (A), plasma (B), yeast extract $(\mathrm{C})$ and plasma + yeast extract $(\mathrm{D})$ diets.

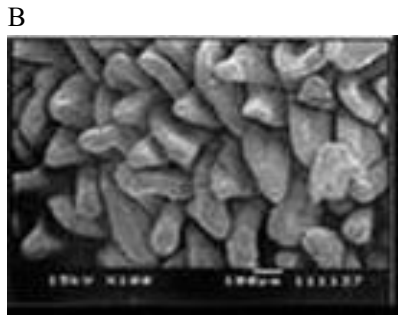

D

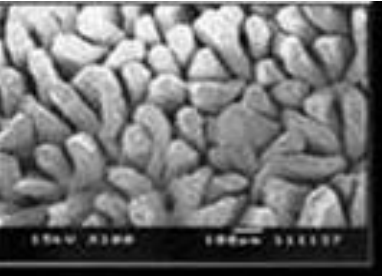

$\mathrm{B}$

\section{References}

APPLEBY, M.C.; PAJOR, E.A.; FRASER, D. Effects of managment options on creep feeding by piglets. Animal Production, v.53, p.361-366, 1991.

ARGENZIO, R.A. Digestão, absorção e metabolismo. In: Dukes: fisiologia dos animais domésticos. 10.ed. Rio de Janeiro: Guanabara Koogan, 1984. p.253-272.

BERTOL, T.M. Efeito de diferentes fontes protéicas sobre o desempenho, composição corporal e morfologia intestinal em leitões. Revista Brasileira de Zootecnia, v.29, p.1735-1742, 2000.

CARLSON, M.S.; VEUM, T.L. A comparison between feeding peptide and plasma protein on the nursery pig growth 
performance and intestinal health. Columbia, Missouri: University of Missouri, 2000. p.13-19.

CARVER, J.D. Dietary nucleotides: cellular immune, intestinal and hepatic system effects. Journal Nutrition, v.124, p.144-148, 1994.

CASTILLO, W. Efeito da substituição do farelo de soja pela levedura (Saccharomyces cerevisiae) como fonte protéica em dietas para leitões desmamados sobre a morfologia intestinal e atividade das enzimas digestivas intestinais. Archivos Latinoamericanos de Producción Animal, v.12, p.21-27, 2004.

CERA, K.R.; MAHAN, D.C.; CROSS, R.F. Effects of age, weaning and postweaning diet on small intestinal growth and jejunal morphology in young swine. Journal of Animal Science, v.66, p.574-584, 1988 .

COSTA, L.L. Plasma animal e extrato de levedura em dietas para leitões desmamados aos 21 dias de idade: desempenho e respostas fisiológicas. 2006. 97f. Tese (Doutorado em Zootecnia) Universidade Federal de Lavras, Lavras.

DOMENEGHINI, C.; GIANCAMILLO A.; SAVOINI, G. Strutural patterns of swine ileal mucosa following L-glutamine and nucleotide administration during the weaning period: An histochemical and histometrial study. Histology Histopathology, v.19, p.49-58, 2004.

FERREIRA, A.S.; SOBESTIANSKY, J.J.; LIMA, G.J.M.M. Início de arraçoamento e dietas para leitões lactentes. Desempenho na maternidade e na creche. Revista da Sociedade Brasileira de Zootecnia, v.21, p.847-854, 1992.

HALL, G.A.; BYRNE, T.F. Effects of age and diet on small intestinal structure and function in antibiotic piglets. Veterinary Science, v.47, p.387-392, 1989.

HAMPSON, D.J. Alterations in piglet small intestinal structure at weaning. Veterinary Science, v.40, p.322-340, 1986.

HANCOCK, J.D. Effects of ethanol extraction and heat treatment of soybean flakes on function and morphology of pig intestine. Journal Animal Science, v.68, p.3244-3251, 1990.

HANSEN, J.A.; NELSSEN J.L.; GOODBAND, R.D. et al. Evaluation of animal protein supplements in diets of early-weaned pigs. Journal Animal Science, v.71, p.1853-1862, 1993.

JENSEN, P.; ALGERS, B.; STEINWALL, L. Behavior and weight changes at weaning and regrouping of pigs in relation to meat quality. Animal Science, v.26, p.143-155, 1997.

JIANG, R.; CHANG, X.; STOLL, B. et al. Dietary plasma protein reduces small intestinal growth and lamina propria cell density in early weaned pigs. Journal Nutrition, v.130, p.21-26, 2000.

KATS, L.J.; NELSSEN, J.L.; TOKACH, M.D. et al. The effect of spray-dried porcine plasma on growth performance in the earlyweaned pig. Journal Animal Science, v.72, p.2075-2081, 1994.
KISHIBUCHI, M.; TSUJINAKA, T.; YANO, M. Effects of nucleoside and nucleotide mixture on gut mucosal barrier function on parenteral nutrition in rats. Journal Parenteral and Enteral Nutrition, v.21, p.104-111, 1997.

KLURFELD, D.M. Nutritional regulation of gastrointestinal growth Frontiers in Bioscience, v.4, p.9-21, 2002.

LI, D.F.; NELSSEN, J.L.; REDDY, P.G. et al. Interrelationship between hypersensitivity to soybean proteins and growth performance in early-weaned pigs. Journal Animal Science, v.69, p.4062-4069, 1991.

LOPES, D.C.; DONZELE, J.L.; ALVARENGA, J.C. Avaliação de épocas do início do arraçoamento de leitões em aleitamento. Revista da Sociedade Brasileira de Zootecnia, v.15, p.219-223, 1986.

MAKKINK, C.A.; NEGULESCU, G.P.; GUIXIN, Q. et al. Effect of dietary protein source on feed intake, growth, pancreatic enzyme activities and jejunal morphology in newly-weaned piglets. British Journal Nutrition, v.72, p.353-368, 1994.

McCRACKEN, B.A.; SPURLOCK, M.E.; ROOS, M.A. et al. Weaning anorexia may contribute to local inflammation in the piglet small intestine. Journal Nutrition, v.129, p.613-619, 1999.

PAJOR, E.A.; FRASER, D.; KRANER, D.L. Consumption of solid food by suckling pigs: individual variation and relation to weight gain. Animal Science, v.32, p.139-155, 1991.

ROPPA, L. Nutrição de leitões na fase pós-desmame. In: CONGRESSO NORDESTINO DE PRODUÇÃO ANIMAL, 1., 1998, Fortaleza. Anais... Fortaleza, 1998. p.265-271.

ROSTAGNO, H.S.; ALBINO, L.F.T.; DONZELE, J.L. et al. Tabelas brasileiras para aves e suínos: Composição de alimentos e exigências nutricionais. Viçosa, MG: Universidade Federal de Viçosa, 2005. 186p.

SANDERSON, I.R.; HE, Y. Nucleotide uptake and metabolism by intestinal epithelial cells. Journal Nutrition, v.124, p.131-137, 1994.

STEIN, H.H. The effects of adding spray dried plasma protein and spray dried blood cells to starter diets for pigs. In: SIMPÓSIO LATINO-AMERICANO DE NUTRIÇÃO DE SUÍNOS E AVES/ CBNA, 1996, Campinas. Anais... Campinas, 1996. p.70-86.

TSUJINAKA, T.; KISHIBUCHI, M.; IIJIMA, S. Nucleotides and intestine. Journal Parenteral Enteral Nutrition, v.23, p.74-77, 1999.

UAUY, R.; STRIGEL, G.; THOMAS, R. Effect of dietary nucleosides of growth and maturation of the developing gut in rat. Journal Pediatric Gastroenterology Nutrition, v.10, p.497-503, 1990.

van DIJK, A.J.; EVERTS, H.; NABUURS, M.J.A. et al. Growth performance of weanling pigs fed spray-dried animal plasma: a review. Livestock Production Science, v.68, p.263-274, 2001.

WILSON, M.R. Immunological development of the young pig. Journal Animal Science, v.38, p.1105-1112, 1974. 